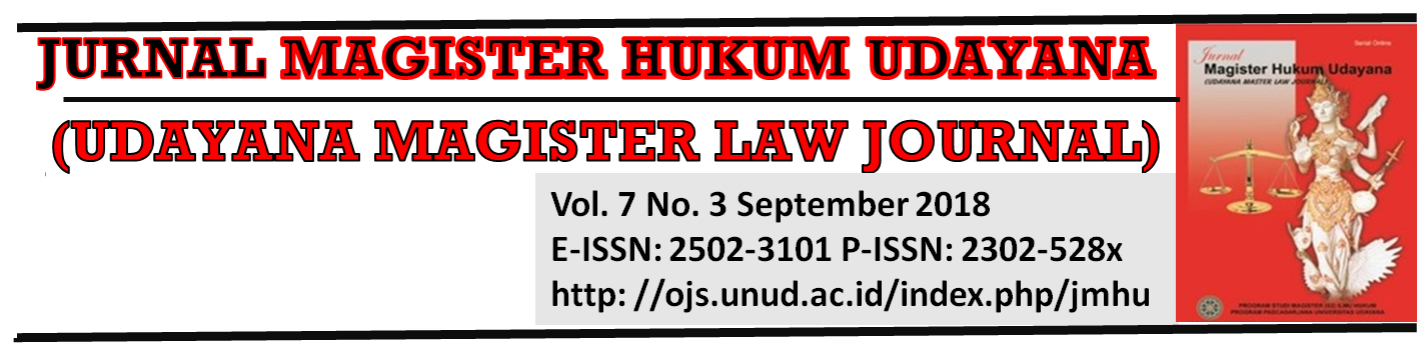

\title{
Pengaturan dan Pengawasan Produk Pangan Olahan Kemasan
}

\author{
Edy Nurcahyo ${ }^{1}$
}

${ }^{1}$ Fakultas Hukum Universitas Muhammadiyah Buton

E-mail: edy.nurcahyo@umbuton.ac.id

\begin{tabular}{l} 
Info Artikel \\
\hline Masuk: 11 September 2018 \\
Diterima: 28 September 2018 \\
Terbit: 30 September 2018 \\
Keywords: \\
Regulation; Supervision; \\
Processed Food Products \\
\\
Kata kunci: \\
Pengaturan; Pengawasan; \\
Produk Pangan Olahan \\
Corresponding Author: \\
Edy Nurcahyo, E-mail: \\
edy.nurcahyo@umbuton.ac.id \\
DoI:
\end{tabular}

\begin{abstract}
The article aims to describe marketing permits and forms of supervision of food products in the packaging food industry. A large number of food product in circulation that does not meet the requirements and standards stipulated in the regulation can be a problem and endanger human safety. Therefore the existence of marketing permits and supervision of food products is very important to maintain food security. The research method used is normative juridical legal research, which is a library research by examining library material related to the object under study. The research uses a statute approach and provides qualitative analysis. The results of the research show that the food industry products are circulated, they must have a marketing permit, if it is ignored, it will be subject to criminal and administrative sanctions. The purpose of supervision is to provide consumer protection and prevent the circulation of food that endangers consumers. Supervision is carried out in a preventive and repressive means.

Abstrak
Artikel ini bertujuan untuk mendeskripsikan izin edar
serta bentuk pengawasan produk makanan industri
pangan kemasan. Banyaknya produk pangan yang beredar
tidak memenuhi syarat dan standar yang diatur dalam
Undang-Undang dapat menjadi masalah dan
membahayakan keselamatan manusia. Oleh karena itu
keberadaan izin edar dan pengawasan produk pangan
sangat penting untuk menjaga keamanan pangan. Metode
Penelitian yang digunakan adalah penelitian hukum
yuridis normatif, yaitu sebuah penelitian kepustakaan
dengan cara meneliti bahan pustaka terkait objek yang
diteliti. Pada penelitian ini menggunakan pendekatan
perundang-undangan (statute approach). Analisis yang
digunakan berupa analisis kualitatif. Hasil penelitian
menunjukan bahwa sebelum produk industri pangan
diedarkan harus memiliki izin edar, bila hal itu diabaikan
akan dikenakan sanksi pidana dan sanksi administratif.
Tujuan pengawasan adalah untuk memberikan
perlindungan konsumen dan mencegah beredarnya
makanan yang membahayakan konsumen. Pengawasan
dilakukan secara preventif dan represif.
\end{abstract}




\section{Pendahuluan}

Pangan merupakan kebutuhan dasar manusia, oleh karena itu, industri pangan merupakan industri yang akan selalu tumbuh, paling tidak mengikuti pertumbuhan penduduk. Tidak heran jika industri pangan, terutama industri skala kecil bermunculan untuk memenuhi permintaan tersebut. Proses pengolahan pangan pada umumnya tidak memerlukan tingkat teknologi dan penguasaan ilmu pengetahuan yang rumit. Oleh karena itu hampir semua orang dapat memulai usaha atau industri pangan ini. Menurut catatan BPS (2004) jumlah industri pangan skala rumah tangga pada tahun 2003 mencapai 950.872 buah. Jumlah ini jauh lebih besar dibandingkan jumlah industri pangan skala besar dan menengah yang jumlahnya hanya mencapai 4.597 perusahaan (BPS, 2004) Industri Rumah Tangga Pangan (IRTP) biasanya dicirikan dengan tempat usaha yang sama dengan tempat tinggal dan menggunakan peralatan pengolahan pangan manual hingga semiotomatis. ${ }^{1}$

Pertumbuhan industri makanan dan minuman pada Tahun 2017 mencapai sebesar 9,23 persen lebih tinggi bila dibandingkan dengan pertumbuhan industri non-migas yang mencapai 4,84 persen. Hal ini menunjukkan bahwa sektor industri makanan dan minuman mempunyai peran yang sangat besar dalam pertumbuhan ekonomi di Indonesia. ${ }^{2}$ Menurut catatan Kementerian Perindustrian, laju industri makanan dan minuman pada triwulan ketiga 2017 mencapai 9,46 persen atau diatas pertumbuhan ekonomi nasional sekitar 5,06 persen pada periode yang sama. ${ }^{3}$

Pangan telah menjadi kebutuhan dasar manusia yang paling utama dan pemenuhannya merupakan bagian dari hak asasi manusia sebagai komponen dasar untuk mewujudkan sumber daya manusia yang berkualitas. Negara juga memiliki kewajiban dalam mewujudkan ketersediaan, keterjangkauan, dan pemenuhan konsumsi pangan yang cukup, aman, bermutu, dan bergizi seimbang.

Dari hasil pengawasan Badan Pengawas Obat dan Makanan (BPOM) tahun 2016 menunjukkan sekitar 14,9 persen dari 26.537 sampel pangan tidak memenuhi syarat karena penyalahgunaan bahan berbahaya, cemaran mikroba atau bahan tambahan pangan (BTP) melebihi batas maksimum yang diizinkan. BPOM mencatat, di Indonesia dalam kurun waktu 2011 dan 2015, produk makanan yang tidak sesuai dengan standar yang diterapkan meningkat sekitar 35 persen. Diantaranya sejumlah zat berbahaya yang digunakan sebagai zat aditif untuk makanan dan adanya kontaminasi mikroba.

${ }^{1}$ Hariyadi, P. \& Hariyadi, R. D. Petunjuk Sederhana Memproduksi Pangan Yang Amana. Available from. https://repository.ipb.ac.id/handle/123456789/58556? show=full

2 Puspa, A.W. (2018 Pebruari 26). Pabrikan Makanan dan Minuman Skala Kecil Diminta Perhatikan Kemasan Produk. Bisnis.com. Retrieved from http://industri.bisnis.com/read/20180226/257/743321/pabrikan-makanan-minuman-skalakecil-diminta-perhatikan-kemasan-produk

3 Juandi, A. (2018 Agustus 22). Industri Makanan dan Minuman Berpotensi Tumbuh di Tahun Politik. Elshinta.com. Retrieved from. http://elshinta.com/news/134976/2018/01/31/industri-makanan-dan-minumanberpotensi-tumbuh-di-tahun-politik 
Pada tahun 2013 sampai 2015, laporan tentang keracunan makanan yang serius meningkat dari 48 menjadi 61 kasus di 34 provinsi. ${ }^{4}$

Menurut catatan BPOM (2017), ditingkat produksi pangan, pada tahun 2017 telah dilakukan pemeriksaan terhadap 4.057 sarana industri yang terdisi atas $1.705(42.03 \%)$ industri pangan MD (industri besar dan bersifat lokal) dan 2.352 (57.97\%) industri rumah tangga pangan (IRTP) yang sudah memiliki nomer pendaftaran PIRT. Dari data tersebut dilakukan pemeriksaan yang memfokuskan pada Cara Produksi Pangan Olahan yang Baik (CPPOB) dan kepatuhan terhadap undang-undang. Dari hasil pemeriksaan sarana industri pangan MD memperlihatkan bahwa 974 sarana $(57,13 \%)$ sudah menerapkan CPPOB, sedangkan 652 sarana $(38,24 \%)$ belum menerapkan CPPOB secara konsisten. Sementara itu, hasil pemeriksaan IRTP diketahui bahwa 258 $(10,97 \%)$ sarana telah menerapkan CPPOB untuk IRTP, 1.953 (83,04\%) sarana belum menerapkan CPPOB untuk IRTP. ${ }^{5}$ Dari data tersebut menunjukkan adanya masalah dalam peningkatan mutu produksi yang harus diawasi dan ditangani secara serius agar tidak merugikan konsumen pangan.

Peristiwa keracunan jajanan di sekolah juga terjadi di berbagai tempat secara merata di Indonesia dalam beberapa decade terakhir. Data dari Direktorat Surveilan dan Penyuluhan Keamanan Pangan BPOM menunjukkan bahwa di tahun 2004 telah terjadi Kejadian Luar Biasa (KLB) keracunan makanan sebanyak 164 di Indonesia dengan cakupan kasus sebanyak 7.336 dan 51 meninggal dunia. ${ }^{6}$

Keamanan pangan olahan kemasan juga menjadi sesuatu yang sangat penting untuk melindungi konsumen dari segala bentuk produk pangan yang merugikan dan/atau membahayakan kesehatan. Sehingga setiap produk pangan olahan kemasan yang beredar harus dipastikan keamanannya sesuai standar dan syarat tertentu sebagaimana diatur dalam peraturan perundang-undangan yang berlaku.

Standar keamanan pangan diatur dalam Pasal 140 Peraturan Pemerintah Nomor 28 Tahun 2004 tentang Keamanan, Mutu dan Gizi Pangan: Setiap orang yang memproduksi dan memperdagangkan Pangan yang dengan sengaja tidak memenuhi standar keamanan pangan, dipidana dengan pidana penjara paling lama 2 (dua) tahun atau denda paling banyak Rp. 4.000.000.000,00 (empat miliar rupiah).

Persyaratan keamanan pangan menjadi perhatian serius agar dapat mencegah pangan dari kemungkinan adanya bahaya, baik karena cemaran biologis, kimia, dan benda lain yang dapat mengganggu, merugikan, dan membahayakan kesehatan manusia. Bagi konsumen muslim, pangan yang aman tidak hanya sekedar terbebas dari bahaya fisik, kimia ataupun mikribiologi, tetapi juga ada unsur yang sangat hakiki, yaitu aman

4 Riska Putri, Melisa. (2017 April 3). Keamanan Pangan tanggung Jawab Semua Pihak. Republika. Retrieved from https://republika.co.id/berita/ekonomi/makro/17/04/03/ontwdm415-bpom-keamananpangan-tanggung-jawab-semua-pihak

5 BPOM. (2017). Laporan Tahunan BPOM Tahun 2017. 132-133 Retrieved from https://www.pom.go.id/new/admin/dat/20180710/Laporan\%20Tahunan\%20BPOM\%2020 17.pdf

6 Selinaswati, S. (2018). Peran Sekolah Dalam Antisipasi Keracunan Pangan Jajanan Anak Sekolah-PJAS. SOCIUS, 4(2), 127-134. 
dari bahaya barang yang diharamkan dan diragukan. Motif ekonomi untuk mencari keuntungan dari produksi dan perdagangan panganan kemasan sering kali mengabaikan persyaratan keamanan pangan yang diperdagangkan tersebut.

Moral hazard dari pelaku usaha makanan dan minuman kemasan seringkali merugikan konsumen, dimulai dengan kualitas produk makanan dan/atau minuman yang kualitasnya tidak baik, informasi kemasan yang tidak jelas, tidak memiliki izin edar. Semua tindakan moral hazard tersebut telah banyak ditemukan oleh Badan Pengawas Obat dan Makanan (BPOM), umumnya kasus tersebut seperti tidak memiliki izin edar, tidak ada logo SNI, dan tidak ada label halalnya, dan makanan mengandung bahan pengawet berbahaya.

Sebagai salah satu contoh dari kasus di atas yaitu ditemukannya pelanggaran oleh pembuat snack bikini. BPOM pada tahun 2016 menemukan adanya pelanggaran yang dilakukan oleh pembuat makanan ringan bihun kekinian (bikini). Produk makanan kemasan tersebut dinyatakan telah melanggar 4 peraturan. Pertama, melanggar Undang-Undang RI Nomor 18 Tahun 2012 Tentang Pangan; Kedua, melanggar Peraturan Pemerintah Nomor 69 Tahun 1999 Tentang Label dan Iklan Pangan; Ketiga, melanggar Undang-Undang Nomor 8 Tahun 1999 Tentang Perlindungan Konsumen; Keempat, melanggar Undang-Undang Nomor 44 Tahun 2008 Tentang pornografi. ${ }^{7}$

Oleh karena itu untuk menjaga keamanan pangan, keberadaan izin edar produk pangan olahan kemasan sangat penting, karena untuk mendapatkan izin edar harus mengikuti serangkaian uji laboratorium dan verifikasi dokumen sebelum dinyatakan layak dan mendapatkan izin edar. Selain izin edar, pengawasan terhadap produk pangan olahan kemasan juga sangat penting untuk melindungi konsumen dan mencegah adanya pelanggaran yang dilakukan oleh pelaku usaha pangan.

Berdasarkan uraian tersebut, artikel ini hendak membahas bagaimana pengaturan dan pengawasan produk pangan olahan kemasan?; dan bagaimana perlindungan hukum terhadap konsumen dari produk pangan olahan kemasan yang beredar di pasaran?

\section{Metode Penelitian}

Metode Penelitian yang digunakan adalah penelitian hukum yuridis normatif, yaitu sebuah penelitian kepustakaan dengan cara meneliti bahan pustaka terkait objek yang diteliti. Pada penelitian ini menggunakan pendekatan perundang-undangan (statute approach). Pendekatan perundang-undangan tersebut digunakan untuk mengkaji dan menganalisis semua peraturan perundang-undangan yang berkaitan dengan objek yang diteliti yaitu semua perundang-undangan yang berkaitan dengan pengaturan dan pengawasan produk pangan olahan kemasan. Analisis yang digunakan berupa analisis kualitatif yaitu analisis data dengan memberikan deskripsi atas temuantemuan untuk menjawab rumusan masalah yang diteliti.

\footnotetext{
7 Michico, N. R. (2016 Agustus 8). Pembuat Snack Bikini Langgar Empat Peraturan. Detik News. Retrieved from http://news.detik.com/berita/3270781/bpom-pembuat-snack-bikinilanggar-4-peraturan. hal 1
} 


\section{Hasil dan Pembahasan}

\subsection{Regulasi dan Pentingnya Izin Edar Produk Pangan Olahan Kemasan}

Regulasi yang mengatur izin edar produk pangan olahan kemasan dapat ditemukan dalam berbagai peraturan perundang-undangan antara lain sebagai berikut:

a) Undang-Undang Nomor 36 Tahun 2009 Tentang Kesehatan.

Pasal 111 ayat (2): Makanan dan minuman hanya dapat diedarkan setelah mendapat izin edar sesuai dengan ketentuan peraturan perundang-undangan.

b) Undang-Undang Nomor 18 tahun 2012 Tentang Pangan.

Pasal 83 ayat (1): Setiap orang yang melakukan Produksi Pangan untuk diedarkan dilarang menggunakan bahan apa pun sebagai Kemasan Pangan yang dapat melepaskan cemaran yang membahayakan kesehatan manusia.

c) Peraturan Badan Pengawasan Obat dan Makanan Nomor 27 Tahun 2017 Tentang Pendaftaran Pangan Olahan.

Pasal 2 ayat (1): Setiap Pangan Olahan yang diproduksi di dalam negeri atau yang diimpor untuk diperdagangkan dalam kemasan eceran wajib memiliki izin edar.

d) Peraturan Pemerintah Nomor 69 Tahun 1999 Tentang Label dan Iklan Pangan.

Pasal 2 ayat (1): Setiap orang yang memproduksi atau memasukkan pangan yang dikemas ke dalam wilayah Indonesia untuk diperdagangkan wajib mencantumkan Label pada, di dalam, dan atau di kemasan pangan.

e) Peraturan Pemerintah Nomor 28 Tahun 2004 Tentang Keamanan Mutu dan Gizi Pangan.

Pasal 16 ayat (1): Setiap orang yang memproduksi pangan untuk diedarkan dilarang menggunakan bahan apapun sebagai kemasan pangan yang dinyatakan terlarang dan/atau yang dapat melepaskan cemaran yang merugikan atau membahayakan kesehatan manusia.

f) Undang-Undang Nomor 33 Tahun 2014 Tentang Jaminan Produk Halal.

Pasal 38: Pelaku Usaha yang telah memperoleh Sertifikat Halal wajib mencantumkan Label Halal pada: (1) Kemasan Produk; (2) Bagian Tertentu dari Produk; dan/atau (3) Tempat tertentu dari Produk.

Regulasi yang mengatur izin edar makanan dan minuman kemasan terdiri dari beberapa peraturan perundang-undangan serta peraturan pelaksanaannya. Hal tersebut tentu tidak mudah dipahami bagi orang awam yang menjadi pemula untuk membangun usaha baru di bisnis industri makanan dan minuman kemasan. Ketidaktahuan terhadap ketentuan peraturan tersebut membuat pelaku usaha banyak yang mengedarkan produk pangan olahan kemasan tanpa mengikuti ketentuan, syarat, dan standar yang diatur dalam peraturan perundang-undangan. Pelaku usaha yang melanggar dapat terjadi disebabkan ketidaktahuannya akan serangkaian ketentuan yang wajib dilakukan seperti wajib mendapatkan izin edar. Ketidaktahuan pelaku usaha akan peraturan tersebut menjadi penyebab pelaku usaha mengabaikan kewajibannya sebagai pelaku usaha untuk menjaga keamanan pangan bagi konsumen dari produk yang diedarkan. Di sisi lain, bagi konsumen regulasi tersebut sangat penting untuk melindungi konsumen dari segala bentuk makanan dan minuman yang membahayakan, karena keamanan pangan merupakan bagian dari hak konsumen yang harus dipenuhi oleh pengusaha pangan.

Proses pendaftaran produk untuk mendapatkan izin edar bisa dilalui dengan dua cara, yaitu pendaftaran produk secara manual dan pendaftaran produk secara online. Pada pendaftaran manual, beberapa persyaratan berkas yang harus dilengkapi adalah: (1) 
Fotokopi izin industri dari departemen Perindustrian dan Perdagangan atau Badan Koordinasi Penanaman Modal; (2) Berkas asli hasil uji laboratorium yang berhubungan dengan produk dan terdiri dari klaim gizi, zat yang diklaim pada label, uji kimia, cemaran mikrobiologi dan cemaran logam. Hasil analisis lab tersebut berlaku selama 6 bulan; (3) Rancangan label sesuai dengan yang akan diedarkan sekaligus contoh produknya; (4) Formulir pendaftaran yang diisi lengkap. Formulir pendaftaran dapat diperoleh di bagian Tata Usaha Direktorat Penilaian Keamanan Pangan BPOM. Sementara untuk Proses pendaftaran produk secara daring (online) dapat dilakukan dengan mengakses e-Registration Pangan Olahan di website www.bpom.go.id.

Setelah proses pendaftaran produk selesai dan telah memperoleh izin edar, maka produk yang didaftarkan akan mendapat nomor pendaftaran. Sejauh ini ada tiga jenis nomor pendaftaran izin edar yang berlaku untuk produk: (1) PIRT (Pangan Industri Rumah Tangga); (2) Nomor SP (Sertifikat Penyuluhan): nomor pendaftaran yang diberikan kepada pengusaha kecil dengan modal dan pengawas dari Dinas Kesehatan Kabupaten/Kotamadya; (3) Nomor MD: diberikan kepada produsen yang memproduksi produk dengan modal besar yang mampu memenuhi criteria kualitas dan keamanan produk yang ditetapkan pemerintah; (4) Nomor ML: diberikan untuk produk impor, baik berupa kemasan langsung maupun yang dikemas ulang.

Pentingnya izin edar produk pangan olahan kemasan baik bagi pelaku usaha maupun bagi konsumen. Manfaat izin edar produk bagi Pengusaha Pangan, yaitu: (1) Melegalkan produk pangan olahan kemasan yang diedarkan di pasaran; (2) Produk yang sudah legal akan mendapatkan kepercayaan konsumen dan pasar. Sementara itu, manfaat izin edar produk pangan olahan kemasan bagi konsumen, yaitu: (1) Konsumen dalam mengkonsumsi produk pangan yang aman, bebas cemaran kimia, biologi dan fisik; (2) Konsumen memperoleh informasi tentang produk; (3) Konsumen terhindar dari segala bentuk kerugian.

Pengertian izin menurut R. Kosim Adisapoetra diartikan dengan perbuatan pemerintah yang memperkenankan suatu perbuatan yang dilarang oleh peraturan yang bersifat umum. ${ }^{8}$ Pengertian izin tersebut bila dihubungkan dengan izin edar produk pangan olahan kemasan dapat ditarik unsur-unsurnya berupa: (1) pemerintah melalui peraturan perundang-undangan melarang peredaran produk pangan olahan kemasan tanpa adanya izin edar; (2) peraturan yang mengatur tentang izin edar produk pangan olahan kemasan bersifat umum (hukum publik).

Menurut N.M. Spelt dan J.B.J.M Ten Berge, mendefinisikan izin dalam arti sempit yakni pengikatan-pengikatan pada suatu peraturan izin. Pada umumnya didasarkan pada keinginan pembuat undang-undang untuk mencapai suatu tatanan tertentu atau menghalangi keadaan-keadaan buruk. ${ }^{9}$ Dari definisi izin tersebut dapat diulas bahwa instrumen peraturan izin dalam izin edar produk pangan olahan kemasan ditujukan sebagai sarana pengawasan untuk setiap produk pangan yang beredar di pasaran dan

\footnotetext{
8 Adiwibowo, Y. (2016). Epistemologi Ideologi Keamanan Pangan. Yuridika, 1(8), 119-133. https://doi.org/http://dx.doi.org/10.20473/ydk.v31i1.1962

${ }_{9}^{9}$ Hidayat, F. A., \& Basuki, A. (2014). Perizinan Lingkungan Hidup Dan Sanksi Pidana Bagi Pejabat Pemberi Izin. Perspektif, 19(2), 94-103.
} 
juga menjadi sarana untuk memberikan perlindungan kepada konsumen oleh pemerintah.

\subsection{Perlindungan Konsumen dalam Peredaran Produk Pangan Olahan Kemasan}

Perlindungan konsumen dalam peredaran produk pangan olahan kemasan sangat penting bukan saja untuk melindungi konsumen dari segala bentuk kerugian, melainkan juga sangat penting untuk menumbuh kembangkan sikap perilaku usaha yang penuh tanggung jawab. Tanggung jawab pelaku usaha dapat menumbuhkan semangat persaingan usaha yang penuh sportifitas dalam menjaga kepastian mutu, dan keamanan produk yang ditawarkan dalam dunia usaha.

Produk pangan olahan kemasan yang diproduksi dan diperdagangkan oleh pelaku usaha harus memiliki izin edar. Apabila produk pangan olahan kemasan tidak memiliki izin edar hal itu dianggap melanggar hukum karena dapat dipastikan produk tersebut belum sesuai standar mutu yang dipersyaratkan dan diatur dalam peraturan perundang-undangan.

Selain itu, pentingnya izin edar produk pangan olahan kemasan dalam dunia usaha adalah untuk menjamin terpenuhinya hak konsumen. Hak konsumen terhadap produk pangan olahan kemasan yang beredar dapat berupa: (1) Hak atas kenyamanan, keamanan, dan keselamatan dalam mengkonsumsi produk pangan olahan kemasan; (2) Hak untuk memilih serta mendapatkan produk pangan olahan kemasan sesuai dengan nilai tukar dan kondisi jaminan yang dijanjikan; (3) Hak atas informasi yang benar, jelas, dan jujur mengenai kondisi dan jaminan produk pangan olahan kemasan; (4) Hak untuk didengar pendapat dan keluhannya atas produk makanan dan minuman kemasan yang dikonsumsinya; (5) Hak untuk mendapatkan advokasi, perlindungan, dan upaya penyelesaian sengketa perlindungan konsumen secara patut; (6) Hak untuk mendapatkan pembinaan dan pendidikan konsumen; (7) Hak untuk mendapatkan Jaminan Kepastian Halal atas produk pangan olahan kemasan.

Disamping hak-hak konsumen yang telah diatur dalam peraturan perundangundangan sebagaimana diatur dalam Undang-Undang Nomor 8 tahun 1999 Tentang Perlindungan Konsumen, juga diatur kewajiban konsumen dalam Pasal 5. Kewajiban konsumen tersebut adalah sebagai berikut: (1) Konsumen wajib membaca atau mengikuti petunjuk informasi dan prosedur pemakaian atau pemanfaatan setiap produk (barang) dan/atau jasa, demi keamanan dan keselamatan; (2) Beritikad baik dalam melakukan transaksi pembelian produk (barang) dan/atau jasa; (3) Membayar sesuai dengan nilai tukar yang disepakati; (4) Mengikuti upaya penyelesaian hukum sengketa perlindungan konsumen secara patut.

Berkaitan dengan perlindungan konsumen, keseimbangan antara hak dan kewajiban konsumen hendaknya berjalan seimbang. Begitu pula Pelaku Usaha juga harus menjalankan hak dan kewajibannya secara seimbang, agar masing-masing pihak bisa melindungi (protect) kepentingan dirinya dari segala sesuatu yang dapat merugikan diantara kedua belah pihak.

Hak Pelaku Usaha adalah: (1) Hak untuk menerima pembayaran yang sesuai dengan kesepakatan mengenai kondisi dan nilai tukar produk (barang) dan/atau jasa yang 
diperdagangkan; (2) Hak untuk mendapatkan perlindungan hukum dari tindakan konsumen yang beritikad tidak baik; (3) Hak untuk melakukan pembelaan diri sepatutnya di dalam penyelesaian hukum sengketa konsumen; (4) Hak untuk rehabilitasi nama baik apabila terbukti secara hukum bahwa kerugian konsumen tidak diakibatkan oleh barang dan/atau jasa yang diperdagangkan; (5) dan hak-hak yang diatur dalam ketentuan peraturan perundang-undangan.

Berikut ini merupakan kewajiban dari Pelaku Usaha: (1) beritikad baik dalam melakukan kegiatan usahanya; (2) Memberikan informasi yang benar, jelas dan jujur mengenai kondisi dan jaminan barang dan/atau jasa serta memberi penjelasan penggunaan, perbaikan dan pemeliharaan; (3) Memperlakukan dan melayani konsumen secara benar dan jujur serta tidak diskriminatif; (4) menjamin mutu produk (barang) dan/atau jasa yang diproduksi dan/atau diperdagangkan berdasarkan ketentuan standar mutu produk (barang) dan/atau jasa yang berlaku; (5) Memberi kesempatan kepada konsumen untuk menguji , dan/atau mencoba produk (barang) dan/atau jasa tertentu serta member jaminan dan/atau garansi atas produk (barang) yang dibuat dan/atau diperdagangkan; (6) Memberi kompensasi, ganti rugi dan/atau penggantian atas kerugian akibat penggunaan, pemakaian dan pemanfaatan barang dan/atau jasa yang diperdagangkan; (7) Memberi kompensasi, ganti rugi dan/atau penggantian apabila produk (barang) dan/atau jasa yang diterima atau dimanfaatkan tidak sesuai dengan perjanjian.

Konsep pertukaran kepentingan privat (exchange of private interest), dalam konsep ini penulis ingin menjabarkan adanya konsep "pertukaran kepentingan privat" antara Pelaku Usaha dengan Konsumen". Tujuan atau kepentingan utama dari pelaku usaha, khususnya pelaku usaha pangan adalah untuk mendapatkan keuntungan (profit) dari produk yang diproduksi dan/atau diperdagangkan. Keuntungan (profit) mustahil akan didapat bila tidak ada konsumen, sehingga keberadaan konsumen bagi pelaku usaha sangatlah penting. Sebaliknya, konsumen hampir dari semua kebutuhan dasarnya disediakan dan ditawarkan oleh pelaku usaha. Masing-masing pihak antara Pelaku Usaha dan Konsumen bertukar kepentingan melalui sarana transaksi jual beli (transaction).

Masing-masing kepentingan privat dalam proses pertukaran kepentingan privat dapat tercederai karena tidak adanya keseimbangan dari masing-masing pihak dalam menjalankan keseimbangan hak dan kewajiban masing-masing.

Oleh karena itu, untuk menjaga kepentingan privat tersebut dibutuhkan perlindungan (protect) baik dari masing-masing pihak (Pelaku Usaha dan Konsumen) maupun dari pihak ketiga yaitu pemerintah atau kehadiran Negara untuk memberikan perlindungan hukum publik.

Konsep ini menguatkan adanya teori bentuk perlindungan hukum dalam ranah hukum perdata yaitu perlindungan hukum privat dan perlindungan hukum publik. Perlindungan hukum privat melindungi kepentingan privat dan perlindungan hukum publik melindungi kepentingan publik.

Dengan menggunakan pendekatan analisis konsep pertukaran kepentingan privat (exchange of private interest) tersebut, maka dapat disimpulkan bahwa bentuk 
perlindungan konsumen dalam peredaran produk makanan dan minuman kemasan adalah perlindungan hukum privat.

Bentuk perlindungan konsumen dalam peredaran produk makanan dan minuman kemasan bukan hanya dalam bentuk perlindungan hukum privat, namun yang lebih kuat yaitu adanya perlindungan hukum publik.

Bukti adanya perlindungan hukum yang diberikan oleh Negara untuk melindungi konsumen yaitu adanya seperangkat peraturan perundang-undangan berikut ini: (1) Undang-Undang Nomor 8 tahun 1999 Tentang Perlindungan Konsumen; (2) UndangUndang RI Nomor 36 tahun 2009 Tentang Kesehatan; (3) Undang-Undang Nomor 18 tahun 2012 Tentang Pangan; (4) Peraturan Badan Pengawasan Obat dan Makanan Nomor 27 Tahun 2017 Tentang Pendaftaran Pangan Olahan; (5) Peraturan Pemerintah Nomor 28 Tahun 2004 Tentang Keamanan Mutu dan Gizi Pangan; (6) Peraturan Pemerintah Nomor 69 Tahun 1999 Tentang Label dan Iklan Pangan; (7) UndangUndang Nomor 33 Tahun 2014 Tentang Jaminan Produk Halal.

Menurut teori perlindungan hukum (legal protection theory), bentuk perlindungan hukum dibagi menjadi dua bentuk, yaitu: (1) Perlindungan yang bersifat preventif; dan (2) perlindungan represif. ${ }^{10}$ Sementara itu Satjipto Raharjo, perlindungan hukum merupakan upaya pemberian pengayoman terhadap Hak Asasi Manusia (HAM) yang dirugikan orang lain dan perlindungan tersebut diberikan kepada masyarakat agar dapat menikmati semua hak-hak yang diberikan oleh hukum. ${ }^{11}$

Untuk melindungi masyarakat dari produk pangan olahan yang dapat membahayakan kesehatan dan keselamatan, dibutuhkan dua bentuk perlindungan hukum berupa perlindungan hukum yang bersifat preventif dan represif. Pendaftaran izin edar produk sebelum diedarkan merupakan perlindungan hukum bersifat preventif karena dengan adanya izin edar produk akan mencegah terjadinya hal-hal yang membahayakan dan merugikan masyarakat sebagai konsumen dari produk yang beredar. Sementara perlindungan represif yaitu berupa tindakan hukum bagi pihak yang melanggar hukum dengan penyelesaian melalui jalur pengadilan dalam lingkup pengadilan umum.

\subsection{Pengawasan Peredaran Produk Pangan Olahan Kemasan}

Lembaga yang melakukan pengawasan terhadap peredaran produksi makanan dan minuman kemasan yaitu: (1) Badan Pengawasan Obat dan Makanan (BPOM); (2) Kementerian Kesehatan; dan (3) Badan Penyelenggara Jaminan Produk Halal (BPJPH)

Kewenangan BPOM sebagai lembaga yang mengawasi produk pangan olahan kemasan dapat diketahui dalam Keputusan Presiden Nomor 103 Tahun 2001 tentang Kedudukan, Tugas, Fungsi, Kewenangan, Susunan Organisasi, dan Tata Kerja Lembaga Pemerintahan Non Departemen. Tugas BPOM sebagaimana diatur dalam

${ }^{10}$ Salim HS \& Nurbani, E.S. (2013). Penerapan Teori Hukum Pada Penelitian Tesis dan Disertasi. Jakarta: PT. RajaGrafindo Persada, h. 264

${ }^{11}$ Nurcahyo, E \& Khuzaiyah, S. (2018). Perlindungan Hukum Bayi Melalui Pemberian ASI Eksklusif dalam Prespektif Undang-Undang Nomor 36 Tahun 2009 Tentang Kesehatan. Jurnal Cendekia Hukum, 4( 1). 52-64. 
Pasal 67 yaitu melaksanakan tugas pemerintahan di bidang pengawasan obat dan makanan sesuai dengan ketentuan peraturan perundang-undangan yang berlaku.

Demikian halnya Kementerian Kesehatan sebagai lembaga yang juga mempunyai peran mengawasi izin edar produk pangan olahan kemasan dapat diketahui dalam Peraturan Pemerintah Nomor 69 Tahun 1999 Tentang Label dan Iklan Pangan sebagaimana diatur dalam Pasal 59 yaitu pengawasan terhadap pelaksanaan ketentuan tentang Label dan Iklan dilaksanakan oleh Menteri Kesehatan.

Selanjutnya, Badan Penyelenggara Jaminan Produk Halal (BPJPH), berwenang melakukan pengawasan terhadap jaminan produk halal untuk semua produk pangan olahan kemasan yang beredar dapat diketahui dalam Undang-Undang Republik Indonesia Nomor 33 Tahun 2014 Tentang Jaminan Produk Halal. Dalam Pasal 95 Undang-Undang Nomor 18 Tahun 2012 Tentang Pangan juga menyebutkan perihal tanggung jawab pemerintah dalam melakukan pengawasan terhadap penerapan sistem jaminan produk halal.

Dengan mencermati ketentuan di atas sedikitnya dapat dikemukakan ada tiga lembaga yang secara aktif melakukan pengawasan terhadap produk pangan olahan kemasan yang beredar. Bentuk pengawasan yang dilakukan oleh masing-masing lembaga pun memiliki domain yang berbeda. Masing-masing lembaga memiliki tugas dan fungsi yang berbeda. Perbedaan fungsi tersebut dapat diuraikan sebagai berikut.

Badan Pengawas Obat dan makanan (BPOM) mempunyai tugas melaksanakan kebijakan di bidang pengawasan obat dan makanan, Unit Pelaksanaan Teknis di lingkungan BPOM memiliki fungsi sebagai berikut: (1) Penyusunan rencana dan program pengawasan obat dan makanan; (2) Pelaksanaan pemeriksaan secara laboratorium, pengujian dan penilaian mutu produk terapetik, narkotika, psikotropika zat adiktif, obat tradisional, kosmetik, produk komplemen, pangan dan bahan berbahaya; (3) Pelaksanaan pemeriksaan laboratorium, pengujian dan penilaian mutu produk secara mikrobiologi; (4) Pelaksanaan pemeriksaan setempat, pengambilan contoh dan pemeriksaan sarana produksi dan distribusi; (5) investigasi dan penyelidikan pada kasus pelanggaran hukum; (6) pelaksanaan sertifikasi produk, sarana produksi dan distribusi tertentu yang ditetapkan oleh Kepala BPOM; (7) Pelaksanaan kegiatan layanan informasi konsumen; (8) Evaluasi dan penyusunan laporan pengujian obat dan makanan; (9) Pelaksanaan urusan tata usaha dan kerumahtanggaan; dan (10) Pelaksanaan tugas lain yang ditetapkan oleh Kepala BPOM sesuai dengan bidang tugasnya.

Berbeda dengan tugas dan fungsi BPOM, Peran Menteri Kesehatan dalam melakukan pengawasan terhadap peredaran produk pangan olahan kemasan memiliki fungsi pengawasan terhadap pelaksanaan ketentuan tentang Label dan Iklan pada produk yang diedarkan oleh pelaku usaha.

Peran Badan Penyelenggara Jaminan Produk Halal (BPJPH) dalam melakukan pengawasan terhadap produk pangan olahan kemasan memiliki fungsi sebagai penyelenggara jaminan produk halal yang mempunyai wewenang sebagai berikut: (1) Merumuskan dan menetapkan kebijakan Jaminan Produk Halal; (2) Menetapkan norma, standar, prosedur, dan kriteria Jaminan Produk Halal; (3) Menerbitkan dan 
mencabut Sertifikat Halal dan Label Halal pada Produk; (4) Melakukan registrasi Sertifikat Halal pada produk luar negeri; (5) Melakukan sosialisasi, edukasi, dan publikasi Produk Halal; (7) Melakukan akreditasi terhadap Lembaga Pemeriksa Halal (LPH); (8) Melakukan registrasi Auditor Halal; (9) Melakukan pengawasan terhadap Jaminan Produk Halal; dan (10) Melakukan kerja sama dengan lembaga dalam dan luar negeri di bidang penyelenggaraan Jaminan Produk Halal.

Tugas dan fungsi dari lembaga BPOM, Menteri Kesehatan, dan BPJPH dalam mengawasi peredaran produk pangan olahan kemasan bila ditinjau dari teori pengawasan (theory of supervision) akan dapat diberikan tafsiran yang lebih dalam dan luas berkaitan dengan fungsinya sebagai lembaga yang mengawasi peredaran obat dan makanan.

Menurut Lyndal F Urwick, Pengawasan adalah upaya agar sesuatu dilaksanakan sesuai dengan peraturan yang telah ditetapkan dan instruksi yang dikeluarkan. Menurut Henry Fayol, Pengawasan adalah ketetapan dalam menguji apa pun sesuatu persetujuan, yang disesuaikan dengan instruksi dan prinsip perencanaan, yang sudah tidak dapat dipungkiri lagi. ${ }^{12}$

Dengan mencermati definisi pengawasan yang dikemukakan oleh para pakar di atas dapat dikemukakan bahwa pengawasan (supervision) adalah tindakan hukum untuk memastikan objek yang diawasi sesuai dengan peraturan perundang-undangan dan berjalan sesuai prosedural yang berlaku secara legal.

Unsur dalam definisi "pengawasan (supervision) tersebut: (1) Adanya tindakan hukum; (2) Adanya objek yang diawasi; (3) Adanya perintah undang-undang. Dari unsurunsur definisi pengawasan tersebut dapat dijabarkan peran Badan POM dalam melakukan pengawasan terhadap izin edar produk pangan olahan kemasan sebagai berikut: (1) Tindakan hukum yang dilakukan oleh BPOM adalah melakukan pengawasan; (2) Objek yang diawasi adalah izin edar produk pangan olahan kemasan; (3) Perintah Undang-Undang yaitu berupa objek yang semestinya mengikuti prosedural dan aturan yang berlaku, yakni kewajiban mendapatkan izin edar.

Peran BPJPH dalam melakukan pengawasan terhadap produk pangan olahan kemasan adalah sebagai berikut: (1) Tindakan hukum yang dilakukan oleh BPJPH adalah melakukan pengawasan; (2) Objek yang diawasi adalah Jaminan Produk Halal; (3) Perintah Undang-Undang yaitu berupa objek yang semestinya mengikuti prosedur dan aturan yang berlaku, yakni mendapatkan sertifikat produk halal dan mencantumkan label halal pada produk pangan olahan kemasan yang diperdagangkan.

Pengawasan yang dilakukan Badan Pengawas Obat dan Makanan (BPOM) terhadap izin edar pangan olahan kemasan dapat dilakukan dalam bentuk pengawasan langsung (on-site supervision) dan tidak langsung (off-site supervision) serta pengawasan preventif dan pengawasan represif. Pengawasan langsung dilakukan secara pribadi

12 Wawointana, T. V. V., Kaawoan, J. E., \& Rengkung, F. (2017). Fungsi Pengawasan Badan Permusyawaratan Desa (Bpd) Dalam Pengelolaan Anggaran Pendapatan Dan Belanja Desa Tahun 2015 Di Desa Esandom Kecamatan Tombatu Timur. Jurnal Eksekutif, 1(1). 
dengan cara mengamati, meneliti, memeriksa, mengecek sendiri ke tempat produk makanan dan minuman kemasan diedarkan seperti supermarket dan minimarket dengan cara inspeksi. Sedangkan pengawasan tidak langsung dilakukan dengan cara mempelajari dan menindaklanjuti laporan dari masyarakat. Pengawasan preventif dilakukan melalui pembinaan terhadap Pelaku Usaha Pangan yang belum mengedarkan produk pangan agar segera mengupayakan adanya izin edar. Pengawasan represif dilakukan dengan cara pemeriksaan terhadap produk pangan olahan kemasan yang sudah beredar di pusat-pusat perbelanjaan dengan cara inspeksi.

\subsection{Sanksi Pelanggaran Izin Edar Produk Pangan Olahan Kemasan}

Ketentuan Pasal 111 ayat (2) Undang-Undang Nomor 36 Tahun 2009 Tentang Kesehatan mewajibkan setiap produk pangan olahan yang diedarkan harus terlebih dahulu mendapatkan izin edar sesuai ketentuan peraturan perundang-undangan yang berlaku. Apabila pada realitanya ada pelaku usaha yang memproduksi pangan olahan kemasan untuk diperdagangkan belum memiliki izin edar, maka pelaku usaha pangan dapat meminta kepada BPOM untuk dilakukan pembinaan berkaitan tata cara mendapatkan izin edar. Bila pelaku usaha dengan sengaja mengedarkan produk pangan olahan kemasan tidak memiliki izin edar maka pelaku usaha tersebut dapat dikenakan sanksi sebagaimana diatur dalam Undang-Undang Nomor 18 Tahun 2012 Tentang Pangan, yaitu ancaman 2 tahun penjara dan denda maksimal 4 (empat) miliar rupiah.

Pasal 142 Undang-Undang Nomor 18 Tahun 2012: Pelaku Usaha Pangan yang dengan sengaja tidak memiliki izin edar terhadap setiap Pangan Olahan yang dibuat di dalam negeri atau yang diimpor untuk diperdagangkan dalam kemasan eceran sebagaimana dimaksud dalam Pasal 91 ayat (1) dipidana dengan pidana penjara paling lama 2 (dua) tahun atau denda paling banyak Rp. 4.000.000.000,00 (empat miliar rupiah).

Dalam pasal tersebut, dapat dipahami bahwa setiap pelaku usaha pangan wajib memiliki izin edar untuk setiap pangan olahan yang hendak diedarkan dalam bentuk kemasan eceran. Bila kewajiban untuk memiliki izin edar diabaikan dengan sengaja maka pelaku usaha pangan yang bersangkutan diancam pidana penjara atau denda.

Pasal 91 ayat (1) Undang-Undang Nomor 18 Tahun 2012, perihal kewajiban Pelaku Usaha Pangan untuk memiliki izin edar sebagai berikut: Dalam hal pengawasan keamanan, mutu, dan gizi, setiap Pangan Olahan yang dibuat di dalam negeri atau yang diimpor untuk diperdagangkan dalam kemasan eceran, Pelaku Usaha Pangan wajib memiliki izin edar.

Namun, tidak semua Pangan Olahan wajib memiliki izin edar, hal ini sebagaimana diatur dalam Pasal 91 ayat (2) Undang-Undang Nomor 18 tahun 2012 tentang Pangan, pengecualian tersebut untuk Pangan Olahan yang diproduksi oleh Industri Rumah Tangga (IRT).

Pasal 91 ayat (2) Undang-Undang Nomor 18 Tahun 2012: Kewajiban memiliki izin edar sebagaimana dimaksud pada ayat (1) dikecualikan terhadap Pangan Olahan tertentu yang diproduksi oleh industri rumah tangga. 
Meskipun Pangan Olahan yang diproduksi oleh industri rumah tangga tidak diwajibkan memiliki izin edar, namun menurut Pasal 43 dalam Peraturan Pemerintah Nomor 28 Tahun 2004 Tentang Keamanan, Mutu dan Gizi Pangan, dijelaskan bahwa Pangan Olahan Industri Rumah Tangga (IRT) wajib memiliki Sertifikat Produksi Pangan Industri Rumah Tangga (SPP-IRT) yang diterbitkan oleh Bupati/Walikota.

Produk Pangan Olahan untuk mendapatkan izin edar juga harus menjamin kualitas dari setiap makanan dan minuman yang beredar. Apabila dalam produk pangan olahan yang akan diedarkan terdapat bahan yang berbahaya dan tidak sesuai dengan standar baku maka BPOM tidak akan mengeluarkan izin edar. Pelaku Usaha Pangan bila dengan sengaja mengedarkan produk pangan olahan kemasan yang mengandung bahan berbahaya sesuai dengan Pasal 62 Undang-Undang Nomor 8 Tahun 1999 Tentang Perlindungan Konsumen, diancam pidana 5 (lima) tahun penjara dan denda Rp 2.000.000.000,00 (dua miliar rupiah).

Untuk mendapatkan izin edar, setiap Pelaku Usaha Pangan wajib memiliki kemasan beserta labelnya yang sesuai dengan standar baku yang telah ditetapkan oleh pemerintah. Selain harus mendapatkan izin edar, dalam Pasal 89 Undang-Undang nomor 18 Tahun 2012 Pelaku Usaha juga dilarang memperdagangkan Pangan yang tidak sesuai dengan Keamanan Pangan dan Mutu Pangan yang tercantum dalam label Kemasan Pangan. Bagi Pelaku Usaha dalam memperdagangkan pangan tidak sesuai dengan informasi yang tertera pada label kemasan pangan diancam dengan ancaman penjara paling lama 2 (dua) tahun atau denda maksimal Rp. 4.000.000.000,00 (empat miliar rupiah).

Pasal 141 Undang-Undang Nomor 18 Tahun 2012: Setiap Orang dengan sengaja memperdagangkan Pangan yang tidak sesuai dengan Keamanan Pangan dan Mutu Pangan yang tercantum dalam label Kemasan Pangan sebagaimana dimaksud dalam Pasal 89 dipidana dengan pidana penjara paling lama 2 (dua) tahun atau denda paling banyak $R p$. 4.000.000.000,00 (empat miliar rupiah).

Dalam pasal tersebut, dapat dipahami bahwa pelaku usaha pangan wajib memberikan informasi yang benar, jelas dan jujur mengenai kondisi produk pangan olahan. Apabila pelaku usaha pangan memperdagangkan pangan yang tidak sesuai dengan keamanan pangan dan mutu pangan yang tercantum dalam label kemasan pangan itu berarti tidak adanya itikad baik dari pelaku usaha dan telah mengabaikan kewajiban untuk memberikan informasi yang benar, jelas dan jujur mengenai produk pangan kepada konsumen, perbuatan demikian juga diancam dengan pidana penjara atau denda.

Setiap pelaku usaha juga dilarang mengedarkan pangan tercemar. Pangan tercemar seperti: (1) mengandung bahan beracun, berbahaya, atau yang dapat membahayakan kesehatan atau jiwa manusia; (2) Mengandung cemaran yang melampaui ambang batas maksimal yang ditetapkan; (3) Mengandung bahan yang dilarang digunakan dalam kegiatan atau produksi pangan; (4) Mengandung bahan yang kotor, busuk, tengik, terurai, atau mengandung bahan nabati atau hewani yang berpenyakit atau yang berasal dari bangkai; (5) Diproduksi dengan cara yang dilarang; (6) Sudah kadaluarsa. 
Bila hal itu dilanggar (Pasal 90 ayat 1) mengenai Pangan tercemar, dikenai sanksi administratif. Sanksi administratif tersebut berupa: (1) Denda; (2) Penghentian sementara dari kegiatan, produksi, dan/atau peredaran; (3) Penarikan Pangan dari peredaran oleh produsen; (4) Ganti rugi, dan/atau (5) Pencabutan Izin.

Pelaku usaha juga diwajibkan untuk menjaga kehalalan produk. Dalam Pasal 25 huruf b Undang-Undang Nomor 33 Tahun 2014 Tentang Jaminan Produk Halal menyebutkan bahwa Pelaku Usaha yang telah memperoleh sertifikat halal wajib menjaga kehalalan Produk yang telah memperoleh Sertifikat Halal. Pelaku Usaha yang tidak menjaga kehalalan produk yang telah memperoleh Sertifikat Halal sebagaimana dimaksud dalam Pasal 25 huruf $\mathrm{b}$ dipidana dengan pidana penjara paling lama 5 (lima) tahun atau pidana denda paling banyak Rp. 2.000.000.000,00 (dua miliar rupiah).

\section{Kesimpulan}

Produk pangan olahan kemasan yang beredar di Indonesia harus terlebih dahulu memperoleh izin edar. Izin edar dapat diperoleh melalui serangkaian proses sebagaimana diatur dalam peraturan perundang-undangan. Bila izin edar diabaikan dalam peredaran produk pangan olahan kemasan akan dikenakan sanksi pidana dan sanksi administratif. Pengawasan terhadap produk yang tidak memiliki izin edar dilakukan oleh lembaga Negara non departemen dalam hal ini dilakukan oleh BPOM. Tujuan pengawasan adalah untuk memberikan perlindungan konsumen dan mencegah beredarnya makanan yang membahayakan konsumen. Pengawasan dilakukan secara preventif dan represif.

Perlindungan terhadap konsumen bila ditinjau menggunakan pendekatan konsep pertukaran kepentingan privat (exchange of private interest) maka setiap konsumen bisa melindungi kepentingan privatnya dengan cara ketelitian dan kecermatan dalam memilih produk pangan yang beredar, di antaranya dengan melihat: (1) Kemasan; (2) Label; (3) Izin Edar; (4) Daluwarsa. Bentuk perlindungan hukum terhadap konsumen dari peredaran produk pangan olahan kemasan yang tidak memiliki izin edar yaitu perlindungan hukum preventif dan represif.

\section{Daftar Pustaka}

\section{Buku}

Adisasmito, W. (2008). Analisis Kebijakan Nasional MUI dan BPOM dalam Labeling Obat dan Makanan. Jakarta: Faculty of Public Health Universitas Indonesia.

Salim, H. S., \& Nurbani, E. S. (2013). Penerapan Teori Hukum Pada Penelitian Tesis dan Disertasi. Jakarta: Raja Grafindo Persada.

\section{$\underline{\text { Artikel Jurnal }}$}

Adiwibowo, Y. (2016). Epistemologi Ideologi Keamanan Pangan. Yuridika, 1(8), 119133. https://doi.org/http:// dx.doi.org/10.20473/ydk.v31i1.1962

Hidayat, F. A., \& Basuki, A. (2014). Perizinan Lingkungan Hidup Dan Sanksi Pidana Bagi Pejabat Pemberi Izin. Perspektif, 19(2), 94-103. 
Nurcahyo, E \& Khuzaiyah, S. (2018). Perlindungan Hukum Bayi Melalui Pemberian ASI Eksklusif dalam Prespektif Undang-Undang Nomor 36 Tahun 2009 Tentang Kesehatan. Jurnal Cendekia Hukum, 4( 1). 52-64.

Nurhayati, I. (2009). Efektivitas Pengawasan Badan Pengawas Obat Dan Makanan Terhadap Peredaran Produk Pangan Olahan Impor Dalam Mewujudkan Perlindungan Konsumen. Mimbar Hukum-Fakultas Hukum Universitas Gadjah Mada, 21(2), 203-222. https://doi.org/10.22146/jmh.16265

Selinaswati, S. (2018). Peran Sekolah Dalam Antisipasi Keracunan Pangan Jajanan Anak Sekolah-PJAS. SOCIUS, 4(2), 127-134.

Wawointana, T. V. V., Kaawoan, J. E., \& Rengkung, F. (2017). Fungsi Pengawasan Badan Permusyawaratan Desa (Bpd) dalam Pengelolaan Anggaran Pendapatan dan Belanja Desa Tahun 2015 di Desa Esandom Kecamatan Tombatu Timur. Jurnal Eksekutif, 1(1).

\section{Internet}

Hariyadi, P. \& Hariyadi, R. D. Petunjuk Sederhana Memproduksi Pangan Yang Amana. Available from. https://repository.ipb.ac.id/handle/123456789/58556?show=full

Juandi, A. (2018 Agustus 22). Industri Makanan dan Minuman Berpotensi Tumbuh di Tahun Politik. Elshinta.com. Retrieved from. http://elshinta.com/news/134976/2018/01/31/industri-makanan-danminuman-berpotensi-tumbuh-di-tahun-politik

Michico, N. R. (2016 Agustus 8). Pembuat Snack Bikini Langgar Empat Peraturan. Detik News. Retrieved from http://news.detik.com/berita/3270781/bpompembuat-snack-bikini-langgar-4-peraturan. hal 1

Puspa, A.W. (2018 Pebruari 26). Pabrikan Makanan dan Minuman Skala Kecil Diminta Perhatikan Kemasan Produk. Bisnis.com. Retrieved from http://industri.bisnis.com/read/20180226/257/743321/pabrikan-makananminuman-skala-kecil-diminta-perhatikan-kemasan-produk

Riska Putri, Melisa. (2017 April 3). Keamanan Pangan tanggung Jawab Semua Pihak. Republika. Retrieved from https://republika.co.id/berita/ekonomi/makro/17/04/03/ontwdm415bpom-keamanan-pangan-tanggung-jawab-semua-pihak

\section{Peraturan Perundang-undangan}

Undang-Undang Republik Indonesia Nomor 8 Tahun 1999 Tentang Perlindungan Konsumen

Undang-Undang Republik Indonesia Nomor 18 Tahun 2012 Tentang pangan

Undang-Undang Republik Indonesia Nomor 36 Tahun 2009 Tentang kesehatan 
Peraturan Pemerintah Nomor 69 Tahun 1999 Tentang Label dan Iklan Pangan

Peraturan Pemerintah No. 28 Tahun 2004 tentang Keamanan, Mutu dan Gizi Pangan

Peraturan BPOM Nomor 27 Tahun 2017 Tentang Pendaftaran Pangan Olahan

Keputusan Presiden Nomor 103 Tahun 2001 Tentang Kedudukan, Tugas, Fungsi, Kewenangan, Susunan Organisasi, dan Tata Kerja Lembaga Pemerintahan Non Departemen

\section{Dokumen Lainnya}

BPOM. (2017). Laporan Tahunan BPOM Tahun 2017. 132-133 Retrieved from https://www.pom.go.id/new/admin/dat/20180710/Laporan\%20Tahunan\% 20BPOM\%202017.pdf. 